\title{
BIOCHEMICAL CHANGES INDUCED BY HERBICIDE SENCOR IN ALBINO RAT Rattus norvegicus - ALKALINE PHOSPHATASE AND TRANSAMINASES CHANGES IN PLASMA (LIVER FUNCTION) \\ El-Mahrouky, Fatma S.; Fatma K. Khidr; A. A. M. Abou Hashem and T. M. S. Keshta \\ Plant Protection Research Institute.
}

\begin{abstract}
Data showed non significant increases in ALT and AST activities throughout the tested periods when rats treated with $1 / 4$ and $1 / 2 L_{50}$.Sencore herbicide .except at 5 th week of the test, $1 / 2$ LD $_{50}$ induced a significant increases in ALT and AST activities .Regarding to the ALP activity , 1/4 LD 50 induced a non significant decreases at $1^{\text {st }}, 2^{\text {nd }}$ and $4^{\text {th }}$ week while at $3^{\text {rd }}$ and $5^{\text {th }}$ week showed a non significant increases at the same time 1/2 LD 50 induced a non significant increases except at 2nd week, there was non significant reduction in plasma ALP activity. Regarding to the bilirubin level ,1/4 and 1/2 LD 50 induced a non significant increases for all the tested periods except at $2^{\text {nd }}$ week with $1 / 2$ LD 50 exhibited a significant increases in total bilirubin.
\end{abstract}

\section{INTRODUCTION}

The rising consumption of currently used pesticides in developing countries has led to a number of problems such as insect resistance, toxicity to non-target organisms, environmental pollution, and the health hazards associated with pesticide residues. Accordingly, the side effects of herbicides toxicity on different animals were investigated. El-Deeb (1994) reported cyanox and lebaycide avicides induced a significant increases in the activity of serum alanine and aspartate amino transferase for house sparrow and pigeon .Abdel-Rahim et al. (1997) studied the effect of parathion on male albino rat and said the hepatic toxicity of parathion was evident through the hyperactivation of transaminases indicating a hepatic disorder and damage . El-Mahrouky et al. (2001) found that a gradually significant increases in plasma GOT,GPT and a constant significant decreases in ALP and total protein throughout the all experimental periods when house sparrow and palm dove treated with 1/4 LD50 Methomyl (insecticide).

The present work aims to illustrate effect of sub-lethal doses (1/4 and 1/2 LD50)Sencor herbicide on alanine amino transferase (ALT), A spartat amino transferase(AST), Alkaline phosphatase (ALP) and total bilirubin in plasma of male Albino rat Rattus norvegicus at intervals 1,2,3,4,5 weeks post.treatment.

\section{MATERIALS AND METHODS}

The commercial herbicide : Metribuzin was obtained from Monsanto Company.

Chemical name: 4-amino -6 (1,1dimethyl)- 3-methylthio-1,2,4-triazin - 5(4H) Trade mark : Sencor 
Animals:

Male albino rat Rattus norvegicus (120-150g) body weight were obtained from Helwan breeding station ,Cairo. The animals were given standard diet and water adlibitum for 21 day before experiment .1/4 LD $D_{50}$ $\left(500 \mathrm{mg} / \mathrm{kg} \mathrm{b.w}\right.$.) oral administration was used daily for five weeks to the $1^{\text {st }}$ group of animals and the second group were given $1 / 2 L_{50} 1000 \mathrm{mg} / \mathrm{kg}$ b.w. Sencor. In addition to five rats left without treatment as a check control. Five animals from each group were sacrificed by decapitation at 1,2,3,4 and 5 week post. Treatment .blood samples were collected from decapitated animals in the citrated centrifuge tube and centrifuged at $3000 \mathrm{rpm}$ for 15 minutes. plasma was pipetted in clean and dry test tube and frozen at $20^{\circ} \mathrm{C}$ till used for determination of alanine amino transferase (ALT), aspartate amino transferase (AST), alkaline Phosphatase (ALP) and total bilirubin as indicator for liver function according to Reitman and Frankel (1957)for transferases ALT,AST and Goldbery and Belfied (1971) for ALP and Jendrassik (1938)for bilirubin .Statistical analysis was done using the student "t"test according to sendecor and Cochran(1967).

\section{RESULTS AND DISCUSSION}

Plasma transaminase activities of ALT, AST and ALP were determined as indicators of liver function

\section{1- Change in plasma Alanine amino transferase (ALT) :-}

The action of $1 / 4,1 / 2$ of $L D_{50}$ herbicide Sencore is shown in table (1) Data revealed a non significant increases in ALT activity throughout all tested period except at $5^{\text {th }}$ week post. Treatment. $1 / 2 L_{50}$ induced a significant increase. These results are in agreement with Abdel-Raheem et al (1986) who reported an increase in serum GOT enzyme in rats orally

Administrated with $\mathrm{LD}_{50}$ rodenticide (Warfarin, Racumin) ,but on treatment with sub lethal dose of warfarin, a drastic increase in GOT and GPT levels at 15 days after treatment was recorded .Also Amer et al. (1994) found that acute oral curacron insecticide treatment caused an increase in the activity of GOT and GPT in liver of rat, while there was an increase in the activity of GPT and a decrease in GOT after chronic repeated doses in serum of rat .Mansour et al. (1995) found that effect of oral administration of phenobarbiton (PB) and /or alcohol decreased heptic GPT and GOT activities. EL-Mahrouky et al (2001) reported a gradually significant increase in plasma GOT,GPT and constant significant decrease in ALP in house sparrow and palm dove at all intervals of the test .

2-Change in plasma aspartate amino transferase (AST) :-

Effect of herbicide Sencor $1 / 4$ and $1 / 2 L_{50}$ on plasma AST is shown in table (1) .The results revealed a non significant increase in plasma AST activity at $1 / 4 L_{50}$ herbicide Sencor allover the tested periods except at $1^{\text {st }}$ week there was a non significant decrease in plasma AST, while with $1 / 2$ $\mathrm{LD}_{50}$, a significant increases was recorded at $3^{\text {rd }}$ and $5^{\text {th }}$ week post treatment and a non significant increases at $1^{\text {st }}, 2^{\text {nd }}$ and $4^{\text {th }}$ post treatment. These results are in accordance with that obtained by Hassanin (1994) who reported that rats treated with chronic lead acetate displayed a significant elevations in 
serum aminotransferases enzymes GOT and GPT, However, the letter enzyme was highly affected in response to treatment than GOT. Also AbdelAziz et al. (1997)found that a highly significant increase occurred in SGPT activity at 14,21 and 28 days post -treatment with $1 / 4 L D_{50}$ of Calciferol which induced a significant increase at $1^{\text {st }}$ and $14^{\text {th }}$ day post-treatment only . The possible mechanism involved in ALT and AST release may be due to tissue damage or due to increased synthesis or decreased catabolism of tranaminases (Tordior and Van Heemstra-lequire (1980).

3-Change in plasma alkaline phosphatase (ALP) :-

$1 / 4 L D_{50}$ herbicide Sencor induced a non significant reduction in ALP activity at $1^{\text {st }}, 2^{\text {nd }}$ and $4^{\text {th }}$ week post-treatment as soon as a significant increase recorded at $3^{\text {rd }}$ and $5^{\text {th }}$ week post-treatment while $1 / 2 L_{50}$ induced a non significant increases allover the tested periods except at $2^{\text {nd }}$ week there was a non significant reduction table (1) these finding are in agreement with Levi et al. (1987) who reported that hypercalcemia caused a significant decrease in ALP due to effect of vitamin $D$ on rat renal cells . the same results recorded by Abd EL-Raheem et al. (1986), Guven et al. (1990), Hassanin (1994), Abd EL-Aziz et al. (1997) who reported that acute 1/4LD 50 calciferol rodenticide induced a significant increase in serum ALP throughout all treated periods while $1 / 16 \mathrm{LD}_{50}$ revealed a significant increase in its level at 1,7 and 14 days post-treatment only .

4-changes in total Bilirubin :

Bilirubin is formed when hemoglobin is metabolized by the reticuloindothelial system .Bilirubin is protein bound in plasma and conjugated in liver. Plasma bilirubin levels have been used as an indicator of liver function (Burtis, and Ashwood, 1994).Data in table(1) revealed that a non significant increase in plasma bilirubin with $1 / 4$ LD 50 and $1 / 2 L_{50}$ Sencor allover the tested periods, except at $2^{\text {nd }}$ week, there was a significant increase. These results are in agreement with Carpenter et al. (1961). The increase in plasma bilirubin levels may be due to some causes of over production of bilirubin such as intravascular hemolysis. El-Mahrouky et al. (1997) revealed that total bilirubin was significantly increased in rats treated with single $1 / 4 \mathrm{LD}_{50}$ calciferol at 1,3 days while the changes were non significant in the rest period .Repeated 1/16 LD 50 calciferol induced a significant increase at 7,14 and 21 days, while at 1 and 3 and 28 days post-treatment, the changes were non significant . These changes may be due to defect in liver function produced from hepatocellular damage. At the same time Al-Sahhaf (1995) revealed that total bilirubin and creatinine showed a significant increase in treated toads with lannate .Also Abd el-Khalik (1985) indicated that non significant changes were observed in the values of serum total bilirubin of chicken affected by flocoumafen rodenticides. Also EL-Essely (2002) Found that there was a non significant increase in plasma AST, ALT and ALP activity for male and female albino rat with $1 / 10$ and $1 / 4 L_{50}$ of Chloropheacinone and Warfarine rodenticides while a marked decrease in the activity of AST,ALT and ALP in liver and kidney of male and female albino rats were recorded. EL-Mahrowky et al. (2003) reveald that total bilirubin was significantly increased in rats treated with herbicide Machete daily $1 / 4 L_{50}$ at $1^{\text {st }}, 2^{\text {nd }} 3^{\text {rd }}$ and $4^{\text {th }}$ weeks post treatment. 
El-Mahrouky, Fatma S. et al.

T1

11394 
Rezk (2006) found that the effect of 1/3LD50of zinc phosphide on aspartat amino transferase (AST) and alanine amino trasferase (ALT) levels in the liver, kidney and plasma of the wild rat (Rattus norvegicus), Rattus Rattus and A.cahirinus were determined after 1/2, 1,2,4,7,10 and 15 day posttreatment, the levels of AST and ALT gradually decreased in both liver and kidney of 3 tested wild rat, R.norvegicus $R$. rattus and Acahirinus at the beginning of the test while the test while there were gradually increases after 7 days to 15 days .

\section{REFERENCES}

Abdel-Aziz,A.; El-Mahrouky, F.;El-Deeb,H. and El-Halwagy ,M. (1997): Biochemical changes induced by Calciferol Rodenticide in Albino rat (Rattus norvegicus) 2-AlkalinePhosphatase and transaminases changes in Serum J. Egypt. Ger, Soc. Zool. Vol (24) A, Comparative physiology. 205-215

Abdel-Bar, R.(2007): Physiological changes Induced By Anticoagulant Rodenticides In Albino Rats .M.Sc. Thesis, Faculty of Sci. Zoology Department Benha University .

Abdel-Khalik, M.M.(1985): Toxicological studies on the rodenticide flocoumafen. Ph.D. Degree, Forensic medicine, Toxicology and veterinary regulation .Cairo university .

Abdel-Raheem,K.; El-Mossallamy ,N.;El-Elaimy,I. and EID ,Z.(1986): Induced of anticoagulant rodenticides changes in hematology and blood chemistry of rats treated with Warfarin and racumin. Bull. Fac. Sci. Cairo Univ. Vol.54:341-361.

Abdel -Rahim ,E.A.; H.K.Said and Nadia El-Hawashy (1997):Sub chronic adverse effect of Parathion on male albino rat (Rattus Norvegicus). Egypt. J. Agric .Res.,75(1):69-81

Al-Sahhaf ,Z.Y.(1995):Haematological changes induced by a carbonate insecticide lannate in the toad Bufo tibamicus.J.Egypt. Ger. Soc. zool. vol 18(A)comparative Physiology 89-102.

Amer,T.A.; Ibrahim,H.A.; Badawy, M.E and EL-Sawi, M.R. (1994): Curacron toxicity one sone rat liver functions.1-Nucleic acid metabolism and transaminases activity. J. Egypt Ger.Soc.zool.14(A)comparative Physiology. 123-141.

Burtis ,C.A. and Ashwood, E.R.(1994):"Tietz text book of clinical chemistry "2nd ed. W.B. Saunders co.philadelphia, London, Toronts, Mexico City, Tokyo.

Carpenter, C.P.; Weil, C.S.; Palm P.E.; Woodside ,M.W.; Nair, J.H. and Smyth, H.F.Jr. (1961): Mammalian toxicity of 1-naphthyl-Nmethylcarbamate (Sevin insecticide )J. Agric. Food Chem.9:30-39.

El-Deeb, H.I.; A.M. Abd-EL-Gawad ;N.H. Essa and F.K. Khaider (1994): Transferases activites in fledglings of house sparrow, Passer domesticus niloticus and pigeon, Columba livia domesticus sprayed with cyanox and lebaycide avicides during their incubation period. J. Egypt, Ger, Soc. Zool.,Vol, 15(A) Comparative Physiology 7-11. 
El-Essely, E.A.(2002):Chemosterilant effect of some rodenticides on albino rat. M.Sc. Thesis ,Fac.Sci.Cairo univeristy

EL-Mahrouky ,F.; El - Deeb,H.; Ahmady ,A.A.and EL-Halawy ,M. (1997): Biochemical changes induced by Calciferol Rodenticide in Albino rat (Rattus norvegicus). Metabolites changes in serum .J.Egypt. Ger.Soc. Zool. Vol 24(A) Comparative Physiology 217-227.

EL-Mahrouky ,F.; A.E.Sanad and F.Khidr (2001):Effect of Methomyl and leaves Ethanol extract on some Transaminases enzymes and total protein in Birds. J. Agric. Sci. Mansoura Univ., 26(10):6437-6450

EL-Mahrouky, F.;Fatma K. Khidr; S.M. Abdel. Aal and H.A. Zedan (2003): Histological effects of Herbicide (Machete)on the kidney of Albino rat. J. Agric. Sci. Mansoura Univ.,28(6) :5043-5051.

Guven , Y.;Kasapoglu, C.,Yildirim, S. And Gumru,O.(1990) : Toxic doses of cholecalciferol vitamin D3,on alkaline phosphatase levels in serum and gingival tissue of rat. J. Nihn Univ.Sch.Dent., 32(2):77-80.

Goldberg , D.M. and Belfied, A.(1971): Colorimetric method for estimation of alkaline phosphatase in serum and tissue .Znzyme12:561

Hassanin , L.AM.M.(1994):The effect of lead pollution on suseptibility of rats to anticoagulant rodenticide. M.Sc. Thesis, Fac. Sci. Cairo. Univ. Jendrass; K.(1938) Biochem.Z.297,4

Levi,M.; Molitoris , B.A.,Burke , T.J. and Schrier , R.W. (1989):Effect of Vitamin $D$ induced chronic hypercalcemia on rat renal cortical plasma membranes and mitochondria . Am.J.physiol.252(part2)pp 267-275.

Mansoura, A.; Abdel -Raheem, K.; El-Massalamy, N; El-Yamany, N.and Mahmoud, S.(1995):Impact of chronic administration of ethanol and or phenobarbiton and drug with drawal on transaminases and protein in blood and liver of albino rats. J. Egypt. Ger. Soc. Zool.,16 (A) comparative physiology:429-450.

Reitman, S.M.D. and Frankel,S.(1957):A colourmetric methods for the determination of serum glutamic oxaloacetic and glutamic pyruvic transaminase.Am.J.Clin.Path.28:56-63

Rezk.A.M.(2006):Teratogenic effect and Biochemical changes due to some Rodenticides on certain Rodent species. Ph.D.Thesis. Fac.Agric. AlAzhar Univ.

Sndecor, G.W.and Cochran , W.G.(1967):Statistical Methods .Sixth Edition . oxford and IBH puplishing company Delhi, $593 \mathrm{pp}$.

Tordior, W.F.and E.A.H. van Heemstra -lequin (1980):Field Studies monitoring exporsure and effects in the development of pesticdes. Elsevier, Amsterdam, Oxford, New york pp 207 
التغييرات البيوكيميائيـة الناتجـة عن المعاملـة بمبيــ الحشـائش سـنكور علـي الفـأر

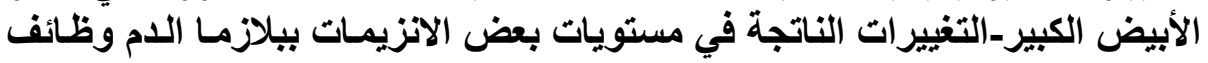

فاطمـة شـوقى المحروقى ، فاطمـة كامـل خضر ، عبد المقصدود عبد المقصود محمد أبو

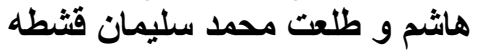

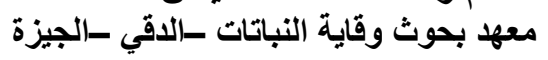

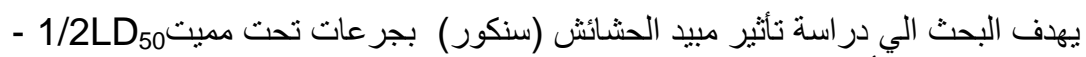

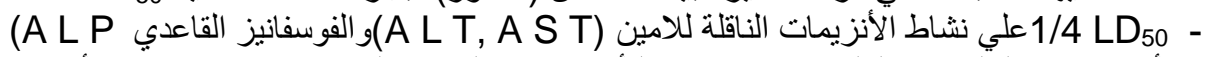

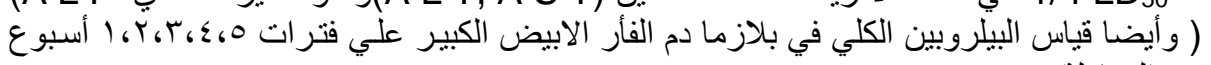

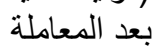

ا- بـ التغيرات في نثاط انزيم A L T, A ST اظهرات المعاملة ب (1/4 LD50-1/2 LD50) زيادة غير معنوية في نشاط الإنزيمين

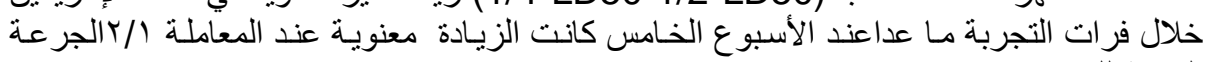

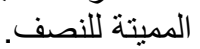

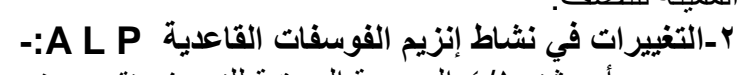

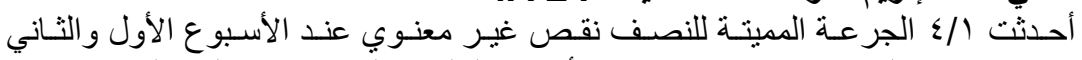

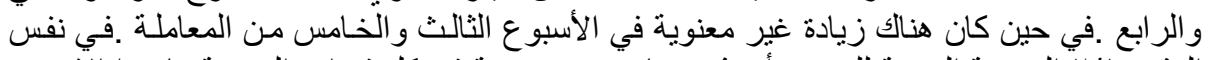

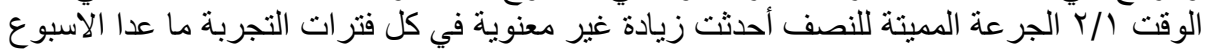

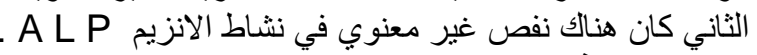

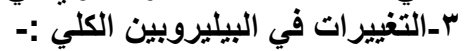

كل من الجرعتين احدثت زيادة غير معنوية في مستوي البيليروبين الكلي في كل فترات

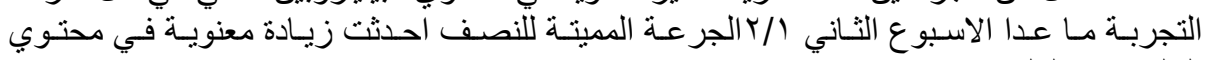
البيليروبين الكلي . وقد نوقثت النتائج في ضوء الابحاث المنشورة .

كلية الزراعة - جامعة المنصورة مركز البحوث الزراعية
قام بتحكيم البحث أ. داء فؤاد عاد عبد الله حسام الدين شاهين أ. دال دال عبد الموجود عبد الله عسران الدين 

J. Agric. Sci. Mansoura Univ., 34 (12): 11391 - 11397, 2009

Table (1): Effect of Herbicide Sencor on Liver function of Albino rat Rattus norvegicus

\begin{tabular}{|c|c|c|c|c|c|c|c|c|c|c|c|c|}
\hline \multicolumn{13}{|c|}{ Days after treatment } \\
\hline Parameters & \multirow{2}{*}{ Dose } & \multirow{2}{*}{$\begin{array}{c}\text { Control } \\
\text { mean } \pm S E\end{array}$} & \multicolumn{2}{|l|}{7} & \multicolumn{2}{|l|}{14} & \multicolumn{2}{|l|}{21} & \multicolumn{2}{|l|}{28} & \multicolumn{2}{|l|}{35} \\
\hline Plasma & & & mean $\pm S E$ & \%diff & mean $\pm S E$ & \%diff & mean $\pm \mathrm{SE}$ & \%diff & mean $\pm \mathrm{SE}$ & \%diff & mean $\pm \mathrm{SE}$ & \%diff \\
\hline$A L T$ & 1/4LD50 & $231.5 \pm 6.3$ & $302.5 \pm 7.3$ & 30.6 & $420.5 \pm 7.8$ & 81.6 & $279.2 \pm 5.2$ & 20.6 & $316.4 \pm 4.8$ & 36.6 & $460.7 \pm 8.2$ & 99.0 \\
\hline $\mathrm{U} / \mathrm{L}$ & 1/2LD50 & $231.5 \pm 6.3$ & $335.2 \pm 9.8$ & 44.7 & $464.4 \pm 7.8$ & 100.6 & $327.2 \pm 7.8$ & 41.3 & $4.2 .7 \pm 4.3$ & 73.9 & $538.1 \pm 5.2$ & 132.4 \\
\hline AST & $1 / 4 \mathrm{LD} 50$ & $212.1 \pm 6.4$ & $210.2 \pm 7.8$ & -0.89 & $231.4 \pm 3.5$ & 9.09 & $291.5 \pm 4.1$ & 37.4 & $331.6 \pm 4.8$ & 56.3 & $314.5 \pm 5.2$ & 48.2 \\
\hline $\mathrm{U} / \mathrm{L}$ & 1/2LD50 & $212.1 \pm 6.4$ & $525.2 \pm 4.5$ & 18.9 & $312.5 \pm 6.5$ & 47.3 & $338.6 \pm 5.7$ & 59.6 & $402.4 \pm 6.6$ & 89.7 & $454.2 \pm 9.0$ & 114.1 \\
\hline$A L P$ & 1/4LD50 & $78.1 \pm 10.1$ & $652.2 \pm 8.5$ & -15.8 & $67.1 \pm 8.1$ & -14.0 & $108.4 \pm 9.1$ & 38.7 & $76.1 \pm 10.1$ & -2.5 & $87.5 \pm 9.1$ & 12.0 \\
\hline $\mathrm{U} / \mathrm{L}$ & 1/2LD50 & $78.1 \pm 10.1$ & $86.5 \pm 7.5$ & 10.7 & $73.5 \pm 10.1$ & -5.8 & $83.5 \pm 10.2$ & 6.9 & $115.1 \pm 7.11$ & 47.3 & $135.0 \pm 12.1$ & 72.8 \\
\hline Total Bilirubin & 1/4LD50 & $0.31 \pm 0.1$ & $0.47 \pm 0.1$ & 51.6 & $0.52 \pm 0.1$ & 67.7 & $0.68 \pm 0.05$ & 119.3 & $0.88 \pm 0.09$ & 183.8 & $1.08 \pm 0.1$ & 248.3 \\
\hline $\mathrm{mg} / \mathrm{dl}$ & 1/2LD50 & $0.31 \pm 0.1$ & $0.62 \pm 0.1$ & 100.00 & $0.95 \pm 0.1$ & 206.4 & $1.02 \pm 0.06$ & 229.0 & $1.10 \pm 0.1$ & 254.8 & $1.44 \pm 0.06$ & 364.5 \\
\hline
\end{tabular}

Each value equal mean \pm S.E. for 5 rat

$P<0.05$ significant

ALT = Albanine amino transferase

AST = Aspatate amino transferas

ALP = Alkaline Phosphatase 